\title{
Phytoprotection
}

\section{Herbicide resistance in the Canadian prairie provinces : Five years after the fact}

\author{
I.N. Morrisson et M.D. Devine
}

Volume 75, numéro 4, 1994

Herbicide Resistance Workshop - Edmonton, Alberta - 9 and 10 december 1993

Atelier sur la résistance aux herbicides - Edmonton (Alberta) - 9 et 10 décembre 1993

URI : https://id.erudit.org/iderudit/706067ar

DOI : https://doi.org/10.7202/706067ar

Aller au sommaire du numéro

\section{Éditeur(s)}

Société de protection des plantes du Québec (SPPQ)l

ISSN

0031-9511 (imprimé)

1710-1603 (numérique)

Découvrir la revue

Citer cet article

Morrisson, I. \& Devine, M. (1994). Herbicide resistance in the Canadian prairie provinces : Five years after the fact. Phytoprotection, 75(4), 5-16.

https://doi.org/10.7202/706067ar
Résumé de l'article

La résistance aux herbicides a été reconnue comme un problème pour la première fois dans les Prairies canadiennes, en 1988, quand une sétaire verte (Setaria viridis) résistante à la trifluraline a été détectée au Manitoba, puis une stellaire moyenne (Stellaria média) et un kochia à balais (Kochia scoparia) résistants au chlorsulfuron ont été identifiés en Alberta et en Saskatchewan, respectivement. Depuis lors, le nombre de mauvaises herbes résistantes s'est accru pour inclure la folle avoine (Avena fatua) résistante aux triallates, ainsi qu'aux aryloxyphénoxypropionates et aux cyclohexanediones (herbicides du groupe 1), la sétaire verte aux herbicides du groupe 1, la soude roulante (Salsola pestifer) et la moutarde des champs (Sinapis arvensis) résistantes au sulfonylurées et aux imidazolinones (herbicides du groupe 2), et finalement la moutarde des champs résistante aux herbicides régulateurs de croissance (herbicides du groupe 4). Les niveaux et patrons de résistance croisée aux molécules des groupes 1 et 2 diffèrent énormément entre les différentes populations, avec des facteurs de résistance (rapport de résistant à sensible [R:S]), obtenus à l'aide de courbes de réponse aux doses, se classant de $<2$ à > 150. La résistance de la sétaire verte au groupe 1 et la résistance de la stellaire moyenne et du kochia à la classe 2 sont dues à des sensibilités réduites des enzymes-cibles: l'acétyl coenzyme-A carboxylase (ACCase) et l'acétolactate synthase (ALS), respectivement. Les mécanismes de résistance pour les autres espèces, incluant la folle avoine résistante aux inhibiteurs de rACCase (groupe 1) et aux triallate/difenzoquat (groupe 8) sont obscurs. À présent, le seul cas de résistance multiple dans l'ouest canadien est la sétaire verte résistante aux éléments chimiques des groupes 1 et 3 (inhibiteurs de l'ACCase et dinitroanilines). Les préoccupations à venir concernent la sévérité accrue de la résistance aux groupes 1 et 8 dans les Prairies, et la possibilité de sélectionner pour la résistance multiple chez les mauvaises herbes du type de la sétaire verte, contre lesquelles il existe peu d'alternatives efficaces. 


\title{
Herbicide resistance in the Canadian prairie provinces: Five years after the fact
}

\author{
Ian N. Morrison ${ }^{1}$ and Malcolm D. Devine ${ }^{2}$
}

Received 1993-11-30; accepted 1994-07-27

Herbicide resistance was first recognized as a problem on the Canadian Prairies in 1988 when trifluralin-resistant green foxtail (Setaria viridis) was reported in Manitoba, and chlorsulfuron-resistant chickweed (Stellaria media) and kochia (Kochia scoparia) in Alberta and Saskatchewan, respectively. Since then, the number of resistant weeds has increased to include wild oats (Avena fatua) resistant to triallate and to aryloxyphenoxypropionate and cyclohexanedione (group 1) herbicides, green foxtail to group 1 herbicides, Russian thistle (Salsola pestifer) and wild mustard (Sinapis arvensis) to sulfonylurea and imidazolinone (group 2) herbicides, and wild mustard to growth regulator (group 4) herbicides. The levels and patterns of cross-resistance to chemicals in groups 1 and 2 vary widely among different populations, with resistance factors [resistant to susceptible (R:S) ratios] derived from dose response curves typically ranging from $<2$ to $>150$. Group 1 resistance in green foxtail and group 2 resistance in chickweed and kochia populations are due to reduced sensitivities of the target enzymes, acetyl coenzyme-A carboxylase (ACCase) and acetolactate synthase (ALS), respectively. The mechanisms of resistance in the other species including wild oats resistant to ACCase inhibitors (group 1) and to triallate/difenzoquat (group 8) are unclear. At present, the only instance of multiple resistance in western Canada is green foxtail resistant to chemicals in both groups 1 and 3 (ACCase inhibitors and dinitroanilines). Future concerns focus mainly on the increasing seriousness of group 1 and 8 resistance across the Prairies, and on the possibility of selecting for multiple resistance in weeds such as green foxtail for which there are few remaining effective control options.

Morrison, I.N. et M.D. Devine. 1994. La résistance aux herbicides dans les Prairies canadiennes: cinq ans plus tard. PHYTOPROTECTION 75 (Suppl.): 5-16.

La résistance aux herbicides a été reconnue comme un problème pour la première fois dans les Prairies canadiennes, en 1988, quand une sétaire verte (Setaria viridis) résistante à la trifluraline a été détectée au Manitoba, puis une stellaire moyenne (Stellaria media) et un kochia à balais (Kochia scoparia) résistants au chlorsulfuron ont été identifiés en Alberta et en Saskatchewan, respectivement. Depuis lors, le nombre de mauvaises herbes

1. Department of Plant Science, University of Manitoba, Winnipeg, Manitoba, Canada R3T 2N2

2. Department of Crop Science and Plant Ecology, University of Saskatchewan, Saskatoon, Saskatchewan, Canada S7N OWO 
résistantes s'est accrû pour inclure la folle avoine (Avena fatua) résistante aux triallates, ainsi qu'aux aryloxyphénoxypropionates et aux cyclohexanediones (herbicides du groupe 1), la sétaire verte aux herbicides du groupe 1, la soude roulante (Salsola pestifer) et la moutarde des champs (Sinapis arvensis) résistantes au sulfonylurées et aux imidazolinones (herbicides du groupe 2), et finalement la moutarde des champs résistante aux herbicides régulateurs de croissance (herbicides du groupe 4). Les niveaux et patrons de résistance croisée aux molécules des groupes 1 et 2 diffèrent énormément entre les différentes populations, avec des facteurs de résistance (rapport de résistant à sensible [R:S]), obtenus à l'aide de courbes de réponse aux doses, se classant de $<2$ à $>150$. La résistance de la sétaire verte au groupe 1 et la résistance de la stellaire moyenne et du kochia à la classe 2 sont dues à des sensibilités réduites des enzymescibles: I'acétyl coenzyme-A carboxylase (ACCase) et l'acétolactate synthase (ALS), respectivement. Les mécanismes de résistance pour les autres espèces, incluant la folle avoine résistante aux inhibiteurs de l'ACCase (groupe 1) et aux triallate/difenzoquat (groupe 8) sont obscurs. À présent, le seul cas de résistance multiple dans l'ouest canadien est la sétaire verte résistante aux éléments chimiques des groupes 1 et 3 (inhibiteurs de l'ACCase et dinitroanilines). Les préoccupations à venir concernent la sévérité accrue de la résistance aux groupes 1 et 8 dans les Prairies, et la possibilité de sélectionner pour la résistance multiple chez les mauvaises herbes du type de la sétaire verte, contre lesquelles il existe peu d'alternatives efficaces.

\section{Nomenclature of chemical names cited in the text:}

Chlorsulfuron: 2-chloro-N-[[(4-methoxy-6-methyl-1,3,5-triazin-2-yl)amino]carbonyl] benzenesulfonamide; dicamba: 3,6-dichloro-2-methoxybenzoic acid; diclofop-methyl: methyl(士)-2-[4-(2,4-dichlorophenoxy)phenoxy]propanoic acid; difenzoquat: 1,2-dimethyl-3,5diphenyl-1H-pyrazolium; ethametsulfuron: 2-[I[I[4-ethoxy-6-(methylamino)-1,3,5-triazin-2-yl] amino]carbonyl]amino]sulfonyl]benzoic acid; fenoxaprop-p-ethyl: (R)-2-[4-[(6-chloro-2benzoxazolyl)oxy]phenoxy]propanoic acid, ethyl ester; imazethapyr: 2-[4,5-dihydro-4-methyl4-(1-methylethyl)-5-oxo-IH-imidazol-2-yl]-5-ethyl-3-pyridinecarboxylic acid; MCPA: (4-chloro2-methylphenoxylacetic acid; metsulfuron: 2-[l[l(4-methoxy-6-methyl-1,3,5-triazin-2yl)amino]carbonyl]amino]sulfonyl]benzoic acid; sethoxydim: 2-[1-(ethoxyimino)butyl]-5-[2(ethylthio)propyl]-3-hydroxy-2-cyclohexen-1-one; thifensulfuron: 3-[l[I/4-methoxy-6-methyl1,3,5-triazin-2-yl)amino]carbonyl]amino]sulfonyl]-2-thiophenecarboxylic acid; tralkoxydim: 2[1-(ethoxyimino)propyl]-3-hydroxy-5-(2,4,6-trimethylphenyl)cyclohex-2-enone; triallate: $S$ (2,3,3-trichloro-2-propenyl)bis(1-methylethyl)carbamothioate; trifluralin: 2,6-dinitro- $N, N$ dipropyl-4-(trifluoromethyl)benzenamine; 2,4-D: (2,4-dichlorophenoxy)acetic acid.

\section{INTRODUCTION}

From the early 1950s when 2,4-D was first introduced, through the next four decades, farmers on the Canadian Prairies became increasingly reliant on herbicides to control weeds. During this time, cereal and oilseed production more than doubled, the area of summer fallow was reduced by half, and numerous non-traditional crops such as canola (Brassica napus L.), lentils (Lens culinaris L.), field peas (Pisum sativum L.) and sunflowers (Helianthus annuus L.) were commercialized on a large scale. In large part, these changes have been made possible by advances in chemical weed control (Hunter et al. 1990).

One of the first signs that the chemical technology had failings was in 1988 when trifluralin-resistant green foxtail (Setaria viridis (L.) Beauv.) was first identified in southwestern Manitoba 
(Morrison et al. 1989). Neither farmers, the chemical industry, nor the research community had encountered a problem of this nature before. Indeed there were many who could not believe that a product that had worked so well for so many years could suddenly appear so wholly ineffective.

The same year, chlorsulfuronresistant chickweed (Stellaria media (L.) Cyrillo) was identified in Alberta, and kochia (Kochia scoparia (L.) Schrad.) in Saskatchewan and Manitoba. While the problem was not widespread, it attracted the immediate attention of the provincial extension specialists and of the manufacturer, who was facing similar problems with prickly lettuce (Lactuca serriola L.) and kochia in Idaho (Mallory-Smith et al. 1990).

With no first-hand knowledge of resistance, it was necessary to turn to the scientific literature for insights on what factors contributed to the evolution of resistance in weeds. Based partly on published accounts relating mainly to triazine resistance in eastern Canada and the United States, and partly on fallacy, the following perceptions emerged: (1) Resistance is most likely to occur with repeated use of soilapplied chemicals with long residual activity; (2) Resistant weeds are typically less fit than susceptible weeds; (3) Herbicides with multiple sites of action, e.g. growth regulators, are less likely to select for resistance than herbicides with a single target site; (4) Enhanced metabolic detoxification processes in resistant weeds may result in crossresistance among products in different chemical families; (5) The evolution of resistance can be slowed by maintaining a high proportion of susceptible plants in the weed population; and (6) Resistant populations will recover if the selection pressure is removed for 1-3 yr by avoiding spraying, using alternative products or fallowing.

The intent of this paper is to provide background to the problem of herbicide resistance in western Canada and, in light of current evidence, qualify or modify these perceptions.

\section{HISTORY OF RESISTANCE}

Since 1989, the number of herbicideresistant weed species reported in western Canada has increased from three to six (Friesen 1993). The six include the two most important annual grass weeds on the Prairies, wild oats (Avena fatua L.) and green foxtail, both of which are resistant to more than one group of herbicides (Tables 1 and 2).

Herbicides are included in a group when they have a common mode of action (groups 1-7) or when there is evidence that resistance to one herbicide also confers resistance to another, e.g. group 8 , which includes triallate and difenzoquat.

The group concept was developed to simplify the use of herbicide rotation as a means of avoiding or delaying resistance, and was initially prompted by the confirmation of resistance to aryloxyphenoxypropionate (APP) and cyclohexanedione (CHD) herbicides (group 1) in wild oats in 1990 (Heap et al. 1993).

From reviewing herbicide use histories of problem fields, it is evident that resistance to group 2 herbicides, and particularly to chlorsulfuron, can occur after as few as three applications (D. Maurice, personal communication). In most fields where resistance to APP and CHD (group 1) herbicides has been identified, the chemicals were applied about 8-12 times over a 12-15 yr span (Heap et al. 1993). Trifluralin resistance in green foxtail appeared after 8-12 treatments (Morrison et al. 1989), triallate resistance in wild oats after $15 \mathrm{yr}$ or more (O'Donovan et al. 1994), and phenoxy resistance in wild mustard (Sinapis arvensis L.) after two decades or more of heavy use (Heap and Morrison 1992).

\section{RECOGNIZING THE PROBLEM}

Telltale signs of resistance in the field are the appearance of irregularly shaped patches of weeds in treated areas where the herbicide has been 
Table 1. Herbicide groups ${ }^{a}$

\begin{tabular}{|c|c|c|c|}
\hline $\begin{array}{l}\text { Herbicide } \\
\text { group }\end{array}$ & Site of action & Family & Herbicide \\
\hline \multirow[t]{2}{*}{1} & ACCase inhibitors & aryloxyphenoxypropionates & $\begin{array}{l}\text { diclofop-methyl } \\
\text { fenoxaprop-p-ethyl } \\
\text { fluazifop-p-butyl } \\
\text { quizalofop-ethyl }\end{array}$ \\
\hline & & cyclohexanediones & $\begin{array}{l}\text { clethodim } \\
\text { sethoxydim } \\
\text { tralkoxydim }\end{array}$ \\
\hline \multirow[t]{2}{*}{2} & $\begin{array}{l}\text { ALS }^{b} / \text { AHAS }^{c} \\
\text { inhibitors }\end{array}$ & sulfonylureas & $\begin{array}{l}\text { chlorsulfuron } \\
\text { ethametsulfuron } \\
\text { metsulfuron } \\
\text { thifensulfuron } \\
\text { tribenuron }\end{array}$ \\
\hline & & imidazolinones & $\begin{array}{l}\text { imazamethabenz } \\
\text { imazethapyr }\end{array}$ \\
\hline 3 & tubulin disrupters & dinitroanilines & $\begin{array}{l}\text { ethalfluralin } \\
\text { trifluralin }\end{array}$ \\
\hline 4 & - & growth regulators & $\begin{array}{l}\text { clopyralid } \\
\text { dicamba } \\
\text { dichlorprop } \\
\text { MCPA } \\
\text { MCPB } \\
\text { mecoprop } \\
\text { picloram } \\
\text { 2,4-D }\end{array}$ \\
\hline 5 & $\begin{array}{l}\text { photosynthetic } \\
\text { inhibitors (PS II) }\end{array}$ & triazines & $\begin{array}{l}\text { atrazine } \\
\text { cyanazine } \\
\text { metribuzin }\end{array}$ \\
\hline 6 & $\begin{array}{l}\text { photosynthetic } \\
\text { inhibitors }\end{array}$ & hydroxybenzonitriles & bromoxynil \\
\hline 7 & $\begin{array}{l}\text { photosynthetic } \\
\text { inhibitors }\end{array}$ & $\begin{array}{l}\text { substituted } \\
\text { ureas }\end{array}$ & linuron \\
\hline 8 & - & - & $\begin{array}{l}\text { difenzoquat } \\
\text { triallate }\end{array}$ \\
\hline \multicolumn{4}{|c|}{ Other herbicides: EPTC, flamprop-methyl, propanil, TCA and bentazon. } \\
\hline
\end{tabular}


Table 2. Occurrence of herbicide-resistant weeds in western Canada

\begin{tabular}{|c|c|c|c|c|c|c|}
\hline \multirow[b]{2}{*}{ Species } & \multirow{2}{*}{$\begin{array}{l}\text { Herbicide } \\
\text { group }\end{array}$} & \multicolumn{2}{|c|}{ First report } & \multicolumn{2}{|c|}{ Current distribution } & \multirow{2}{*}{$\begin{array}{c}\text { Resistance } \\
\text { factor } \\
\text { (R:S ratio) }\end{array}$} \\
\hline & & Year & Province & No. of fields & Province & \\
\hline \multirow[t]{5}{*}{ Green foxtail } & 1 & 1991 & $\mathrm{MB}^{\mathrm{a}}$ & 12 & MB & 5 to $>100$ \\
\hline & 3 & 1988 & MB & $>100$ & MB & 4 to 10 \\
\hline & & & & 90 & SK & \\
\hline & & & & 2 & $A B$ & \\
\hline & 1 and 3 & 1992 & MB & 1 & MB & as above \\
\hline \multirow[t]{5}{*}{ Wild oats } & 1 & 1990 & MB & $>100$ & MB & 5 to $>150$ \\
\hline & & & & 3 & SK & \\
\hline & & & & 7 & $A B$ & \\
\hline & 8 & 1989 & $A B$ & 2 & MB & $\begin{array}{l}\text { triallate: } \\
1.5 \text { to } 8\end{array}$ \\
\hline & & & & $\begin{array}{c}44 \\
1\end{array}$ & $\begin{array}{l}\mathrm{AB} \\
\mathrm{BC}\end{array}$ & $\begin{array}{c}\text { difenzoquat: } \\
6 \text { to } 16\end{array}$ \\
\hline Chickweed & 2 & 1988 & $\mathrm{AB}$ & 15 to $>20$ & $A B$ & 2 to 16 \\
\hline \multirow[t]{3}{*}{ Kochia } & 2 & 1988 & $\mathrm{MB}, \mathrm{SK}$ & 3 & MB & 2 to $>100$ \\
\hline & & & & 47 & SK & \\
\hline & & & & 1 & $A B$ & \\
\hline Russian thistle & 2 & 1989 & SK & 1 & SK & - \\
\hline \multirow[t]{2}{*}{ Wild mustard } & 2 & 1992 & MB & 1 & $\mathrm{MB}$ & - \\
\hline & 4 & 1991 & MB & 9 & MB & 5 to 100 \\
\hline
\end{tabular}

${ }^{a}$ MB: Manitoba; SK: Saskatchewan; AB: Alberta; BC: British Columbia.

applied at, or close to, the recommended rate and other target weeds are killed. Sometimes the infested areas are very large, covering five or more hectares. In situations where the problem has obviously been developing over several years, resistant weed densities can be very high, sometimes an order of magnitude higher than reported as maximum densities in previous surveys (Thomas and Wise 1988). For example, at one of the sites where trifluralinresistant foxtail was identified, there were places in the field where the foxtail density exceeded 25000 plants $\mathrm{m}^{-2}$. At another site where group 1 resistant wild oats was present, the wild oats density was over 2000 plants $\mathrm{m}^{-2}$ in places.
In discussing the use of predictive models, Gressel and Segel (1990) indicated that resistance is generally first recognized as a problem when $30 \%$ of the weeds present within a population are not controlled effectively. However, given the scale of agriculture as practised in western Canada, it is very difficult to identify a problem in its early stages of development, or to ascertain that a certain proportion of the total weed population is no longer being adequately controlled. In fact, resistance usually comes to light when areas of the field become so heavily infested with weeds that significant crop losses occur. The use of such a rule of thumb $(30 \%$ escape) presumes that farmers are aware that resistance can 
occur and that fields are carefully monitored after herbicide application. It also presupposes that the resistant weeds exist as a constant proportion of the total weed numbers over the whole field. Clearly, these circumstances do not exist in the majority of situations encountered in western Canada.

In nearly all instances where resistance has occurred, there has been heavy reliance on one group of herbicides with a common mode of action to control weeds. In most but not all cases, the weed that developed resistance was the primary target species. An exception is the sulfonylurea-resistant wild mustard from northwestern Manitoba. In this situation, hemp nettle (Galeopsis tetrahit L.) was the primary target. After two applications of chlorsulfuron, one of metsulfuron and two of thifensulfuron between 1983 and 1990, followed by the use of ethametsulfuron in canola in 1992, hemp nettle was no longer a prob- lem and resistant wild mustard was the dominant weed, occurring at densities of up to 132 plants $\mathrm{m}^{-2}$ (M. Long, personal communication). The scenario here is similar to that which occurred in Idaho, where resistant prickly lettuce emerged as the dominant weed in fields in which chlorsulfuron was targeted primarily for kochia and Russian thistle (Salsola pestifer A.Nels.) control (Mallory-Smith et al. 1990).

\section{Characteristics of resistant weeds} Most of the weeds that have developed resistance in western Canada are common species, ranking high in terms of relative abundance (Table 3 ). Relative abundance is a composite measure, comprising the relative frequency, relative field uniformity and relative mean density of each species (Thomas and Wise 1987). However, the overall rankings are an average of weed occurrences and may not accurately

Table 3. Rankings of six herbicide-resistant weed species according to their relative abundance and highest recorded densities in the 1986 Saskatchewan Weed Survey ${ }^{a}$

\begin{tabular}{|c|c|c|c|c|}
\hline \multirow[b]{2}{*}{ Species } & \multirow[b]{2}{*}{ Soil zone } & \multicolumn{2}{|c|}{ Species ranking } & \multirow[b]{2}{*}{$\begin{array}{l}\text { Highest recorded } \\
\text { density (plants } \mathrm{m}^{-2} \text { ) }\end{array}$} \\
\hline & & $\begin{array}{c}\text { Relative } \\
\text { abundance }\end{array}$ & Density & \\
\hline \multirow[t]{3}{*}{ Green foxtail } & Overall & 1 & 1 & 1593 \\
\hline & Brown & 1 & 1 & 141 \\
\hline & Dark brown ${ }^{b}$ & 1 & 1 & 334 \\
\hline \multirow[t]{3}{*}{ Wild oats } & Overall & 2 & 10 & 187 \\
\hline & Black & 2 & 5 & 113 \\
\hline & Dark gray ${ }^{b}$ & 1 & 3 & 187 \\
\hline \multirow[t]{3}{*}{ Chickweed } & Overall & 19 & 11 & 122 \\
\hline & Black & 22 & 4 & 120 \\
\hline & Dark gray & 12 & 6 & 80 \\
\hline \multirow[t]{3}{*}{ Kochia } & Overall & 30 & 23 & 55 \\
\hline & Brown ${ }^{b}$ & 13 & 6 & 55 \\
\hline & Dark brown & 19 & 22 & 15 \\
\hline \multirow[t]{3}{*}{ Russian thistle } & Overall & 6 & 10 & 174 \\
\hline & Brown $^{b}$ & 4 & 1 & 174 \\
\hline & Dark brown & 5 & 6 & 129 \\
\hline \multirow[t]{3}{*}{ Wild mustard } & Overall & 11 & 12 & 111 \\
\hline & Black $^{b}$ & 9 & 21 & 33 \\
\hline & Dark gray & 13 & 11 & 47 \\
\hline
\end{tabular}

a Adapted from Thomas and Wise (1987). Data are shown for the overall rankings based on the entire province and for the two soil zones in which each species was most prominent.

b Indicates the soil zone in which each species ranked highest in relative abundance. 
reflect the relative abundance in specific soil or climatic zones. For example, although kochia was ranked low overall in Saskatchewan, it ranked considerably higher in the brown soil zone (Table 3).

When ranked in order of the highest density at which weeds were found to occur, particularly within the soil zone in which they are most prevalent, the order changes. Most of the resistant weeds are ranked higher when the ranking is based on the upper limit of weed density found in the field. This suggests that numbers are important; those weeds that occur at the highest densities are more likely to be treated with herbicides, and the more individuals present the greater the likelihood of the population containing one or more resistant mutants.

There does not appear to be any correlation between resistance development and the mating system of the species. Some resistant species are highly selfed whereas others are obligate out-crossers. Mating systems do play an important part in determining the rate of resistance evolution, depending on the genetics of resistance. The role of different mating systems in resistance development and spread is discussed by Jasieniuk and Maxwell (1994).

In reviewing life history information, the deficiency of knowledge of the basic biology and ecology of our common weeds becomes apparent. For example, although weed seed dormancy has been the subject of numerous scientific studies and publications, there is very little information on the rate of turnover of seed under field conditions. Studies of weed seed dormancy (usually under artificial conditions) give an indication of the potential survival of the seeds, but do not tell us the likelihood of seed surviving in agricultural fields for more than $1 \mathrm{yr}$, more than $2 \mathrm{yr}$, etc. under different management systems.

Notwithstanding the foregoing, of the six species under consideration, some have seed that can remain viable for $5 \mathrm{yr}$ or more, e.g. wild mustard, and others for shorter periods of time, e.g. green foxtail and kochia. The seed of all species that have developed resistance will often germinate within 1-2 yr of production. This may be important in the rapid evolution of resistant populations if susceptible seed disappear from the soil seed bank relatively quickly. However, the lack of good information on rates of seed turnover of different species makes it very difficult to assess the importance of this parameter. In summary, only two points that stand out as characteristic features of the six species under consideration: they are all annuals and they typically occur at relatively high densities in areas where they are well adapted.

\section{Risk of selection}

Whereas resistance to chlorsulfuron, trifluralin and triallate conform to the perception that residual herbicides are more likely to select for resistance than short-residual, foliar-applied chemicals, the widespread occurrence of group 1 resistance proves that this is not always the case. Most group 1 herbicides are either non-residual or have very little soil activity. In this respect, a single early-season application will not control successive flushes of weeds.

From this it might be assumed that the selection pressure exerted by group 1 products is not as great as those from groups 2, 3 or 8 . However, because selection pressure is closely correlated to efficacy, it is reasonable to expect that the highly effective group 1 herbicides will select for resistance as quickly as other groups which may be less effective but have greater soil activity.

While weeds that emerge after treatment will not be controlled, most group 1 herbicides are extremely effective over a wide range of leaf stages. As a result, these products are very often applied when the majority (or all) of the target weeds have emerged. In practice, then, these herbicides do control successive flushes of weeds and very few (if any) susceptible weeds remain to produce seed, particularly where the crop is well established and highly competitive. In such situations, the selection pressure exerted by group 1 products is probably equal to that of more persistent herbicides which remain active through a single growing season. 
From a practical perspective it is possible that in the more northerly areas of the Prairies, where the growing season is short, the selection pressure exerted by non-residual group 2 herbicides such as thifensulfuron will be as great as that from more residual compounds such as metsulfuron or imazethapyr. In the absence of herbicide rotation or other measures to curtail the evolution of resistance, the difference in selection pressure imposed by residual and non-residual chemicals will have little impact on the overall rate of evolution of resistant weeds.

This situation may be somewhat unique to areas of the world such as western Canada where the growing season is relatively short and most weeds emerge over a comparatively short time span in late May or early June. In other geographical regions with longer growing seasons, including parts of Europe and the United States where winter crops are grown, weeds emerge over a much longer period. In these situations, the selection pressure exerted by soil-residual chemicals may well be significantly greater than from non-residual compounds.

\section{Mechanisms of resistance}

Knowledge of the mechanisms of herbicide action and resistance provides insight into the different patterns of resistance and cross-resistance found in the field. In addition, knowledge of existing resistance mechanisms can provide a basis on which to predict future developments in resistance and cross-resistance within a particular species. However, this is limited at present by our incomplete understanding of mechanisms of herbicide action and of the different resistance mechanisms that may be operating. In some instances the results of such research are relatively easy to interpret, whereas in others it is much more difficult. Some current examples from western Canada can be used to illustrate these points.

The sulfonylurea herbicides inhibit acetolactate synthase (ALS), an enzyme involved in branched-chain amino acid biosynthesis (Devine et al. 1991). In most documented resistant biotypes, resistance is conferred by an altered form of ALS that is less sensitive to the herbicides (Devine et al. 1991; Saari et al. 1990). The result, at the whole-plant level, is that the resistant biotypes are resistant to all ALS inhibitors to varying degrees, but their sensitivity to herbicides with other target sites is unaltered (Friesen et al. 1993). This is also the case with a green foxtail biotype resistant to acetyl coenzyme-A carboxylase (ACCase) inhibitors (group 1 herbicides, Table 1). ACCase from the resistant biotype is much less sensitive to these herbicides than that from a susceptible biotype (Marles et al. 1993); this confers broad cross-resistarice to all ACCase inhibitors but not to herbicides with other mechanisms of action (Heap and Morrison 1993).

Whereas whole plant resistance to group 2 herbicides is reasonably well correlated with known target site modifications, in other cases it is more difficult to correlate the mechanisms of herbicide action, mechanisms of resistance, and patterns of crossresistance at the whole plant level. As previously indicated, group 1 resistant wild oats populations vary tremendously in their pattern and level of resistance to different group 1 herbicides (Heap et al. 1993). For example, wild oats population UM1 is highly resistant to sethoxydim but only moderately resistant to tralkoxydim and fenoxaprop-p-ethyl. Another population, UM33, is highly resistant to diclofop-methyl and fenoxaprop-pethyl, but not to sethoxydim (Heap et al. 1993). While it is probable that resistance in UM1 may result from a modified target site (M.A.S. Marles and M.D. Devine, unpublished data!, the mechanism of resistance in UM33 and other populations has not been determined.

The resistance mechanism in wild oats and in some annual ryegrass (Lolium rigidum Gaudin) biotypes has been correlated with an altered response of the plasma membrane electrogenic potential (Em) to the herbicides. The $\mathrm{Em}$ is permanently depolarized in susceptible biotypes but 
can recover in resistant biotypes when the herbicide is removed from the treatment solution (Devine et al. 1993b; Häusler et al. 1991). This in itself does not explain resistance, but implicates membrane action in the resistance mechanism.

Recently, it has been shown that diclofop and tralkoxydim uptake into isolated protoplasts and plasma membrane vesicles from leaf tissue of a resistant wild oats biotype is reduced compared to that in a susceptible biotype (Devine et al. 1993c). Restricted uptake, which would prevent access of the herbicides to ACCase in the chloroplast, is a plausible resistance mechanism. However, it is clear from the whole-plant results that several different mutations must exist to confer the different patterns of cross-resistance amongst ACCase inhibitors. Without fully understanding this resistance mechanism, it is difficult to predict the possible patterns of cross-resistance that may occur in wild oats.

A second example that illustrates our lack of understanding of herbicide action and resistance mechanisms concerns triallate and difenzoquat resistance in wild oats. All of the triallate-resistant wild oats samples identified in Alberta are cross-resistant to difenzoquat (O'Donovan et al. 1994). Triallate and other thiocarbamate herbicides inhibit the fatty acid elongase complex, although the exact target site is unknown (Devine et al. 1993a). The site of action of difenzoquat is unknown, although it has been reported to interfere with thymidine incorporation into DNA and with $\mathrm{K}^{+}$absorption (Devine et al. 1993a). The clear cross-resistance to these two herbicides, but not to any others, raises the possibilities that they may act at the same site and that a target site mutation is responsible for both resistances. However, no research has been reported on the mechanism of resistance to these herbicides, and it is impossible to predict how the resistance mechanism may affect susceptibility to other herbicides.

Trifluralin resistance in green foxtail has been linked to an alteration in a microtubule-associated protein (MAP) (Smeda et al. 1992). Again, this is an unexpected result since trifluralin and other dinitroaniline herbicides inhibit cell division by binding to ß-tubulin and interfering with tubulin polymerization (Devine et al. 1993a). In dinitroanilineresistant goosegrass [Eleusine indica (L.) Gaertn.], resistance is conferred by an alteration in the ß-tubulin (Vaughn and Vaughan 1990). The fact that a different resistance mechanism has been identified in green foxtail raises a question as to the role of MAPs in trifluralin action and resistance. Since MAPs are closely involved in microtubule function, it is unlikely that a mutation to a MAP would confer resistance to any herbicide that does not interfere directly with microtubules.

Finally, resistance to 2,4-D, dicamba and other herbicides that interfere with auxin action has been identified in wild mustard (Heap and Morrison 1992). This is another surprising case since there was a presumption that resistance to these products was unlikely to develop. 2,4-D, MCPA and related herbicides had been used intensively for over $40 \mathrm{yr}$, yet there was little evidence of resistance development until very recently. This was partly because of the poorly understood mode of action of these herbicides, which has often been described as involving multiple target sites. However, recent evidence indicates that this resistance is carried by a single gene (M. Jasieniuk, personal communication), and biochemical evidence suggests that a difference in an auxin-binding protein may be the basis for resistance (J.C. Hall, personal communication). In this case, the existence of a resistant mutant may play an important role in determining not only the mechanism of resistance, but the mechanism of action also.

\section{RESISTANCE DECAY}

Regardless of the nature of resistance, an argument is sometimes made that resistance can be avoided by breaking from frequent or continuous use of a particular herbicide group once in 3 or 
4 yr. Support for this argument is either circumstantial, i.e. some farmers have used certain products frequently in a rotation with no problems, or is borne out of the belief that resistant weeds are much less fit than susceptible weeds, and that their proportion in the population declines rapidly in the absence of intensive selection. To subscribe to the first belief is akin to accepting that the game of Russian roulette is innocuous. And while there is little data on the relative fitness of resistant weeds in western Canada, the limited evidence indicates that with the possible exception of phenoxy-resistant wild mustard (D. Debreuil, personal communication), the resistant weeds are no less fit, or only slightly less fit, than susceptible weeds.

From a practical standpoint, it is unlikely that even after discontinuing the use of a particular group for several years would the proportion of resistant weeds decline to a level that would permit regular use of that group again. Similarly, the notion that inundation of a resistant population with susceptible pollen would ameliorate the resistance problem is improbable given that most resistant weeds are highly selfpollinated and, with one exception, resistance appears to be simply inherited as a dominant trait (Jasieniuk and Maxwell 1994).

\section{PROGNOSTICATIONS}

While our knowledge of herbicide resistance has advanced a long way during the past $5 \mathrm{yr}$, it is still impossible to establish absolute truths or make definitive statements about what has happened, or what could happen in the future. It is certain, however, that continued dependence on herbicides to control weeds, especially without rotating among groups, will aggravate the problem further. It is also clear that the problem extends to both residual and non-residual herbicides and to products such as 2,4-D and dicamba which previously were considered low risks.
Variation among populations in levels of resistance, differences in crossresistance patterns and uncertainties concerning the mechanisms of resistance complicate our understanding of the problem. To compound the situation, there are major gaps in our knowledge about the biology and life history of most important weeds. Such information is essential to the development of the reliable models to predict the evolution of resistance, including population growth components, under different cropping regimes and herbicide use practices.

With broad-spectrum herbicides, including those in both groups 2 and 4, it remains a guessing game as to which weed will develop resistance next. There is no ready explanation for why there are so many occurrences of kochia resistance to group 2 products in North America and none for other weeds like redroot pigweed (Amaranthus retroflexus L.), lamb's quarters (Chenopodium album L.) or green smartweed (Polygonum scabrum Moench), all of which occur over a wide geographical area and are major weeds of field crops.

As for groups 1 and 8 , perhaps a lesson can be learned from the situation with trifluralin-resistant green foxtail in Manitoba. Since resistant foxtail was first identified there in 1988, the problem has become so widespread that it is now impossible to estimate the number of infested fields across the Prairies. Based on the foxtail experience, the $>100$ populations of wild oats confirmed to be resistant to either group 1 or group 8 herbicides may represent only a fraction of the number of resistant wild oats populations scattered across the 28 million ha of cultivated land in western Canada. From a recent survey conducted in a single township in Manitoba with a 10-12 yr history of group 1 usage, resistance was detected in $10-15 \%$ of the fields (L. Bourgeois and I.N. Morrison, unpublished data). Given the much expanded use of group 1 products across all of western Canada during the late 1980s and early 1990s, can the rest of the Prairie provinces be far behind? 


\section{ACKNOWLEDGEMENTS}

The authors wish to thank the Natural Sciences and Engineering Research Council of Canada, DowElanco Canada Inc., Cargill Canada Ltd., Sandoz Agro, and the Graminicide Resistance Action Committee (BASF, Zeneca/ICl, DuPont, Hoechst and Rhône-Poulenc) for supporting their research on herbicideresistant weeds. We are also indebted to our many colleagues and students who have contributed countless new ideas and information on the subject.

\section{REFERENCES}

Devine, M.D., M.A.S. Marles, and L.M. Hall. 1991. Inhibition of acetolactate synthase in susceptible and resistant biotypes of Stellaria media. Pestic. Sci. 31: 273-280.

Devine, M.D., S.O. Duke, and C. Fedtke. 1993a. Physiology of herbicide action. Prentice-Hall, Englewood Cliffs, New Jersey. 441 pp.

Devine, M.D., J.C. Hall, M.L. Romano, M.A.S. Marles, L.W. Thomson, and R.H. Shimabukuro. 1993b. Diclofop and fenoxaprop resistance in wild oats is associated with an altered effect on the plasma membrane electrogenic potential. Pestic. Biochem. Physiol. 45: 167-177.

Devine, M.D., S. Renault, and X. Wang. 1993 c. Alternative mechanisms of resistance to acetyl CoA carboxylase inhibitors in grass weeds. Proc. Br. Crop Prot. Conf. - Weeds: 541-548.

Friesen, L.F. 1993. Herbicide Resistance Section Summary. Report of the Research Appraisal and Planning Committee. Expert Comm. Weeds (West. Sect.) Agriculture Canada, Regina, Saskatchewan. p. 418-423.

Friesen, L.F., I.N. Morrison, A. Rashid, and M.D. Devine. 1993. Response of a chlorsulfuron-resistant biotype of Kochia scoparia to sulfonylurea and alternative herbicides. Weed Sci. 41: 100-106.

Gressel, J., and L.A. Segel. 1990. Modelling the effectiveness of herbicide rotations and mixtures as strategies to delay or preclude resistance. Weed Technol. 4: 186-198.

Häusler, R.E., J.A.M. Holtum, and S.B. Powles. 1991. Cross-resistance to herbicides in annual ryegrass (Lolium rigidum). IV. Correlation between membrane effects and resistance to graminicides. Plant Physiol. 97: 10351043.
Heap, I.M., and I.N. Morrison. 1992. Resistance to auxin-type herbicides in wild mustard (Sinapis arvensis L.) populations in western Canada. Proc. Weed Sci. Soc. Am. 32: 55 (Abstract).

Heap, I.M., and I.N. Morrison. 1993. Resistance to aryloxyphenoxypropionate and cyclohexanedione herbicides in green foxtail (Setaria viridis (L.) Beauv.). Proc. Weed Sci. Soc. Am. 33: 62 (Abstract).

Heap, I.M., B.G. Murray, H.A. Loeppky, and I.N. Morrison. 1993. Resistance to aryloxyphenoxypropionate and cyclohexanedione herbicides in wild oat (Avena fatua). Weed Sci. 41: 232-238.

Hunter, J.H., I.N. Morrison, and D.R.S. Rourke. 1990. The Canadian Prairie Provinces. Pages 51-89 in W.W. Donald (ed.), Systems of weed control in wheat in North America. Weed Sci. Soc. Am., Monograph No. 6, Champaign, Illinois.

Jasieniuk, M., and B.D. Maxwell. 1994. Population genetics and the evolution of herbicide resistance in weeds. Phytoprotection 75 (Suppl.): 25-35.

Mallory-Smith, C.A., D.C. Thill, and M.J. Dial. 1990. Identification of sulfonylurea herbicide resistant prickly lettuce (Lactuca serriola). Weed Technol. 4: 163-168.

Marles, M.A.S., M.D. Devine, and J.C. Hall. 1993. Herbicide resistance in Setaria viridis conferred by a less sensitive form of acetyl Coenzyme A carboxylase. Pestic. Biochem. Physiol. 46: 7-14.

Morrison, I.N., B.G. Todd, and K.M. Nawolsky. 1989. Confirmation of trifluralin-resistant green foxtail (Setaria viridis) in Manitoba. Weed Technol. 3: 544-551.

O’Donovan, J.T., M.P. Sharma, K.N. Harker, D. Maurice, M.N. Baig, and R.E. Blackshaw. 1994. Wild oat (Avena fatua) populations resistant to triallate are also resistant to difenzoquat. Weed Sci. 42: 195-199.

Saari, L.L., J.C. Cotterman, and M.M. Primiani. 1990. Mechanism of sulfonylurea herbicide resistance in the broadleaf weed, Kochia scoparia. Plant Physiol. 93: 55-61.

Smeda, R.J., K.C. Vaughn, and I.N. Morrison. 1992. A novel pattern of herbicide crossresistance in a trifluralin-resistant biotype of green foxtail (Setaria viridis (L). Beauv.). Pestic. Biochem. Physiol. 42: 227-241.

Thomas, A.G., and R.F. Wise. 1987. Weed survey of Saskatchewan cereal and oilseed crops. 1986. Weed Survey Ser. Publication 87-1. Agriculture Canada, Regina, Saskatchewan. 251 pp. 
Thomas, A.G., and R.F. Wise. 1988. Weed survey of Manitoba cereal and oilseed crops. 1986. Weed Survey Ser. Publication 88-1. Agriculture Canada, Regina, Saskatchewan. 201 pp.

Vaughn, K.C., and M.A. Vaughan. 1990.

Structural and biochemical characterization of dinitroaniline-resistant Eleusine. Pages 364-375 in M.B. Green, H.M. LeBaron, and W.K. Moberg (eds.), Managing resistance to agrochemicals: fundamental research to practical strategies. Am. Chem. Soc. Symp. Ser. 421, Washington, DC. 